\title{
The Development Dilemma of Female Scientists in the Scientific Community
}

\author{
Jun Liu* \\ An associate professor, Department of Philosophy, Xi'an Jiaotong University, Xi'an 710049, China \\ *Corresponding Author: Jun Liu, An associate professor, Department of Philosophy, Xi'an Jiaotong \\ University, Xi'an 710049, China
}

\begin{abstract}
This article aims to explain the situation of female scientists and further explore the reasons for their difficulties, such as the traditional positioning of social roles, the identification of the scientific community, and the lack of social support. Today, when people's minds are constantly open and concepts are constantly updated, the phenomenon of female scientists being marginalized in the scientific community has gradually attracted social attention. On one hand, women have to earn a place in the patriarchal society through their own abilities and knowledge, and on the other, they have to bear tremendous pressure from public opinion. First of all, this is determined by women's social status. Secondly, the misunderstanding of women's role positioning, especially the way of thinking rooted in people's mind, is that society shapes women into what it wants. Third, female scientists belong to a disadvantaged group in the scientific community. The scientific community has independent evaluation standards for scientific research. The level of scientific research is firstly judged in the scientific community, and the reputation and status of scientists are mainly determined by the scientific community. Due to physical structure and other reasons, women may be inferior to men in terms of physical strength, but they are not inferior to men in intelligence, ability, and communication with others. Therefore, we call on people to understand and support female scientists.
\end{abstract}

Key Words: social community, female scientists, role positioning

\section{INTRODUCTION}

When the wheel of history enters the 21 st century, people's minds are constantly open and concepts are constantly updated. In today's society where people repeatedly discuss the relationship between "disenchantment" and "re-enchantment" of the world, female scientists are still marginalized. No matter in the scientific community, or in the perception of ordinary people, female scientists are in a relatively awkward position, and in many scientific events, women are always absent. Therefore, many scholars have conducted research on the suitability of women for scientific research and whether there is gender discrimination in the scientific community. First of all, I have to affirm that I am not a feminist personally, and I just question whether women's participation in science receives the same support as men. On one hand, women have to earn a place in the patriarchal society through their own abilities and knowledge, and on the other, they have to bear the huge pressure from the public opinion. This situation has been around for a long time. Here in this article, I want to sort out reasons why female scientists are in such a predicament, and call for people's understanding and support for them.

\section{Explore The Root Cause Of The Marginalization Of Female Scientists}

There are also some female scientists familiar to us in in the world, such as Madame Curie, who discovered two natural radioactive elements of radium and polonium, and won the Nobel Prize twice in her life; Jane Goodall, the British biologist who has been committed to the field research of chimpanzees for a long time; Rosalind Elsie Franklin, who has made significant contributions to the discovery of the double helix structure of DNA; and the famous American female scientist Georgeanna Seegar Jones, known as the "Mother of American Test Tube Baby"... But compared to male scientists, female scientists are very few, and the reason is nothing more than the following:

First of all, this is determined by the social status of women themselves. We know that the emergence of anything is not accidental, but a historical choice. Taking China as an example, the social status of Chinese women has always been very low, and this situation can be seen from the long historical 
social changes. From the end of primitive society to the end of feudal society, from body to thought, Chinese women have been imprisoned and marginalized. The society has stipulated the "three obedience and four virtues", "three cardinal guides and five virtues" for women, and which will be used as the final judgement standard for a women's whole life in the future. After the founding of the People's Republic of China, the social status of women has improved, but it is still not good. Women can go out of the house, enter the society, and find a job. However, the traditional positioning of women in the concept is still deeply ingrained in people's principles and value judgments. We can say that women in China still have not received the same treatment as men. The main reasons are the influence of traditional gender culture, the long-term economic dependence, and patriarchal social rule ${ }^{1}$. Until day, the social status of women is still affected by it. The situation in the West is very similar, where before the rise of the feminist movement, women also existed in dependence on men. In Western history, women were confined to the family and rarely had access to social affairs. The political and economic affairs are dominated by men, and the history of Western development is actually a history of men. For example, in the Middle Ages, women could not own property, study and participate in public affairs; at the end of the $19^{\text {th }}$ century, French women had to cover their faces in public places; in some parts of Germany, husbands had the right to sell their wives; and until the last century, women in some areas still did not have the right to vote. And women's social and family status determines their education level, where in families with many children, we can see how unevenly the educational resources are distributed between men and women, often only when men's education is guaranteed, women's education requirements were then adopted.

Secondly, it is the misunderstanding of women's role positioning, especially the way of thinking rooted in people's mind. Simone de Beauvoir once said, "Women are not born, but created." Society molds women into what it wants, and traditional gender culture is one of the main means of social shaping. The term "social gender" is used to refer to the understanding of the differences between men and women formed in social culture, as well as the group characteristics and behavior patterns of women or men formed thereby. The traditional Chinese gender culture is a single male culture, and its root is the patrilineal society dominated by men. Males are the heirs of the family, with relatively stable family status and social relations, while females, as subordinates, are excluded from the main culture. In history, women have always been recognized by the society as daughters, wives, and mothers in their family identities, such as the three times of relocation of Mencius mother (Meng Mu San Qian), and bed warming by Huang Xiang (Huang Xiang Wen Xi). However, few women have been passed down through the ages because of their social, political, or cultural achievements. In the long feudal dynasty, women have been living in a cracked state. Various inequalities between men and women have gradually developed and matured. Some feudal ethics, customs and laws firmly restrain women in the feudal society and let them consciously bury themselves and some traditional ideas even have even influence till now. In politics, economy and culture, women lose their right to speak. A small number of outstanding women have tried hard to prove their abilities, but it is difficult to get the recognition in social concepts. Even in the more enlightened modern society, the professional image of women is rigidly fixed as kindergarten teachers, nurses, etc., which is caused by the lack of social support, from which women gradually parted ways with science.

Third, female scientists belong to a disadvantaged group in the scientific community, and whether they can be recognized by the scientific community determines their scientific research value. The scientific community has independent evaluation standards for scientific research from the society. The level of scientific research is firstly judged within the scientific community, and the reputation and status of scientists are mainly determined by the scientific community. So the achievements of female scientists must firstly be recognized by the scientific community, but it is easy to tell whether a same platform can be given to women in a male-dominated scientific community. According to the research on social stratification of the scientific community, there are many factors that affect stratification, including social attributes, such as age and gender, and non-social attributes, such as scientific talent, energy, and motivation. One of the focuses of the former research is to study the impact of gender on stratification. Women and scientific research are a topic that attracts attention,

\footnotetext{
${ }^{1}$ On the Changes of the Historical Status of Chinese Women, Ling Ge, Li Xiao, Journal of Theory Research, No. 25,2010

${ }^{2}$ Le Deuxième Sexe, Simone de Beauvoir, translated by Zheng Kelu, Shanghai: Shanghai Translation Publishing House, 2011
} 
because in the entire history of science, male scientists have always dominated, and female scientists formed only for a small proportion, while those with outstanding achievements are even rarer. As of the end of the 1980s, among the 400 Nobel Prize winners, there were only 9 women. Therefore, many scholars have conducted research on the suitability of women for scientific research and whether there is gender discrimination in the scientific community. In this field, Zuckerman and J. Cole have published a series of important research results. The article Women in American Science published by the two in 1975 is a pioneering achievement in this field. The article pointed out that women are far fewer than men in terms of the number of educated students, and the number of men in Ph.D. students is twice that of women, and the number of men engaged in scientific research after graduation far exceeds that of women ${ }^{3}$. In 1979, Cole's monograph Fair Science: Women in the Scientific Community came out, which was the first monograph to systematically study female scientists. Cole examined the relationship between gender status and scientific recognition in the American academic circle, that between gender status and the prestige of the institution, that between gender status and salary, and the difference in the productivity of male and female scientists, but he concluded that for female scientists, the degree of discrimination is slight, so whether it is the fact or the members of the scientific community trying to conceal the truth of the marginalization of female scientists is unknown to outsiders.

\section{How To Treat Female Scientists In The Scientific Community}

In the scientific community, how women scientists will be treated and whether there is discrimination against female scientists has now attracted more and more attention in the society. Mary Wollstonecraft ${ }^{4}$ once said, "First of all, I will consider women as noble people. Like men, they are placed in this world to show their talents." Women or men are just human genders, and before this premise, they are born equal as human beings, and there is no need to presuppose their identities and roles. In the book A Vindication of the Rights of Women: with Strictures on Political and Moral Subjects, Mary Wollstonecraft clearly stated that women are not inherently inferior to men, and this will only be revealed when they lack adequate education. She believes that both men and women should be regarded as rational beings, and then conceived the establishment of a social order based on rationality. This view has been accepted by more and more people in today's society.

Due to physical structure and other reasons, women may be far inferior to men in terms of physical strength, but they are not inferior to men in terms of intelligence, ability, and communication with others. In some aspects, such as patience and endurance, women are better than men. This has been confirmed by scientific research results many times.

In today's society, women can stand alone and compete with men in the workplace, and in the family, women also have the right to refuse to bear all housework. After all, women's identity is not just as wives and mothers; in the same way, in the scientific community, women are also fully capable of using their knowledge and talents, and have performances that surprise male scientists, and should not exist as objects to be excluded or ignored. For example, in the process of discovering the double helix structure of DNA, if it were not for the promotion of female scientist Rosalind Franklin, the three male scientists including Frances Crick, James Watson, and Maurice Wilkins would not to successfully break through this scientific barrier, let alone winning the Nobel Prize later. Therefore, female scientists should also be respected and received due courtesy in the scientific community.

\section{CONCLUSION}

In a patriarchal society, female scientists can be said to be a special group in the scientific community, and they are also a disadvantaged group. While bearing various pressures, they also have to compete with the majority of male scientists, which is not easy. Therefore, they need the recognition of the scientific community, the support of the society and the understanding of their relatives. Only in this way can female scientists continue to advance on the road of scientific research. By presenting the

\footnotetext{
${ }^{3}$ The Reviews on the Social Stratification in Science, Sun Ling, Shang Zhicong, Journal of Science of Science and Management of S. \& T., 2011

${ }^{4}$ Mary Wollstonecraft was an $18^{\text {th }}$ century British writer, philosopher and feminist. A Vindication of the Rights of Women: with Strictures on Political and Moral Subjects (1792) is Wollstonecraft's most well-known work. In the book, she argues that women are not inherently inferior to men. This is only revealed when they lack adequate education. She believed that both men and women should be regarded as rational beings, and went on to conceive of the establishment of a social order based on rationality.
} 
social reality of the marginalization of female scientists, this article explores its historical origins and how to solve them. Due to personal limitations, a tight schedule, and limited data, I think the work done is far from enough. This article could only be regarded as a simple organization of materials, which is very rough, lacking in the conception, structure and novelty. I hope that there will be opportunities for further research in this area in the future.

\section{REFERENCES}

[1] Le Deuxième Sexe, Simone de Beauvoir, translated by Zheng Kelu, Shanghai: Shanghai Translation Publishing House, 2011

[2] On the Changes of the Historical Status of CHINESE Women, Ling Ge, Li Xiao, Journal of Theory Research, No. 25, 2010

[3] The Reviews on the Social Stratification in Science, Sun Ling, Shang Zhicong, Journal of Science of Science and Management of S. \& T., 2011

[4] The Soul of Science, Nancy Pearcey, Charles Thaxthon, translated by Pan Botao, Jiangxi People's Publishing House, 2006.

\section{AUTHOR's BIOGRAPHY}

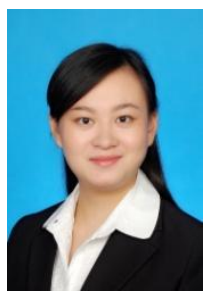

Jun Liu, female, An associate professor, Department of Philosophy, Xi'an Jiaotong University, Xi'an 710049, China.liujun1216@xjtu.edu.cn

Citation: Jun Liu. "The Development Dilemma of Female Scientists in the Scientific Community" International Journal of Humanities Social Sciences and Education (IJHSSE), vol 8, no. 7, 2021, pp. 150-153. doi: https://doi.org/10.20431/2349-0381.0807018.

Copyright: (C) 2021 Authors. This is an open-access article distributed under the terms of the Creative Commons Attribution License, which permits unrestricted use, distribution, and reproduction in any medium, provided the original author and source are credited. 